\title{
Detection and Stimulation of Growth in Children with Developmental Delay in Tegal City
}

\author{
Ratih Sakti Prastiwi, Ulfatul Latifah, Isti Dwi Andari \\ Midwifery Diploma Program, Polytechnic Harapan Bersama \\ Jl. Mataram No.9, Kel. Pesurungan Lor, Margadana, Kota Tegal, Jawa Tengah \\ Email: ratih.sakti@ymail.com
}

\begin{abstract}
Abstrak
Home Schooling merupakan salah satu alternatif pendidikan informal yang dibutuhkan masyarakat bagi anaknya yang mengalami keterlambatan perkembangan dan tidak dapat mengikuti pembelajaran di sekolah formal. Home Schooling memiliki strategi pembelajaran yang unik menyesuaikan kebutuhan peserta didik sehingga dapat mengeskplor kemampuan dan minat secara optimal. Penelitian ini dilaksanakan untuk mengidentifikasi strategi deteksi dan stimulasi tumbuh kembang anak dengan keterlambatan di Kota Tegal. Penelitian ini merupakan penelitian kualitatif dengan pendekatan study fenomenologi. Informan didapatkan melalui teknik sampling snowball yaitu jumlah informan diambil hingga data jenuh. Penelitian ini menggunakan human instrumen dan dianalisis melalui tahapan reduksi-penyimpanan data dan penarikan kesimpulan. Dalam memastikan kebenaran data dilakukan triangulasi metode. Hasil penelitian menunjukkan deteksi dilakukan oleh pendidik dimulai dari seleksi masuk dan selama proses pembelajaran. Strategi stimulasi dilakukan dengan peningkatan kemampuan focus anak. Dengan adanya focus, maka stimulasi yang diberikan mampu diserap dan dikuasai oleh anak dengan baik. Setelah anak mampu untuk focus, stimulasi diberikan sesuai dengan jenis kemampuan yang terdeteksi keterlambatannya. Apabila anak mengalami keterlambatan lebih dari satu macam, maka stimulasi hanya difokuskan pada satu kemampuan terlebih dahulu hingga anak menguasai dengan baik. Stimulasi juga akan berhasil jika stimulasi juga dilakukan oleh orang tua saat anak di rumah.
\end{abstract}

Kata Kunci: deteksi tumbang, stimulasi tumbang, keterlambatan perkembangan

\begin{abstract}
Home Schooling was one of informal education as an alternative for children with developmental delays who could not follow a formal school system. Home Schooling had a unique method of teaching their students based on their ability so they could explore their ability and their interest. This study aimed to identify the strategy to detect and stimulate children with developmental delays in Tegal City. This study was a qualitative study with a phenomenology approach. The researcher used snowball sampling. The data collected through FGD and observation. The researcher did data reduction, data display, and made the decision. The triangulation methods was used to verify the data. The results showed the detection was carried out by educators starting from admission selection and during the learning process. The stimulation strategy was done by increasing the child's focus ability. By having focus, the stimulation provided could be mastered by children optimally. After the child could focus, stimulation was given according to the type of ability that was detected late. If a child experienced more than one kind of delay, then stimulation was only focused on one ability first until the child master it well. Stimulation will also be successful if the stimulation is also carried out by parents when the child is at home.
\end{abstract}

Keywords: detection of developmental, stimulation of developmental, developmental delay 
Article info:

Article submitted on October 28, 2019

Articles revised on January 02, 2020

Articles received on February 22, 2020

DOI: http://dx.doi.org/10.21927/jnki.2020.8(1).58-64

\section{INTRODUCTION}

Every parent hopes their children grow optimally and become the successors of their nation in the future. Therefore parents always try to ensure the development of their children can develop optimally. However, the case of children with developmental delays is uncommon. Especially in other cases, there are children with more than one kind of delay. One to three percent of children under five years are detected having developmental delay. When children with developmental delays are not treated, it can affect their abilities in adult life. They will be less, or they will develop less than $20 \%$ compared to other healthy adults (1-3).

One effort by the Government to overcome the problem of children with developmental delays is detecting early growth and providing interventions for children who were found to be suspicious of having delays. The intended interventions are those carried out by parents, health services, and other elements(4). In order to support those programs, the government try to hook up educational institutions where the detection and stimulation of growth are giving through the education of children from an early age. Children are invited to learn through playing while stimulating fine motor skill development (5). Nowadays, there is a lot of early childhood education which held for children with special needs. The educational institution provides education according to national achievements and helps pursue the achievement of children's developmental abilities. The institution's involvement is beneficial for the government in reducing the incidence of children with developmental delays (6).
Home Schooling is an informal education that used as an alternative by the community for their children who have special needs and cannot attend a formal school like other children. Home Schooling have a unique learning process where learning is given individually according to the child's ability to explore the needs and interests according to the child's character. Tegal City has Home Schooling which provides education for children with special needs; Home Schooling $A B C D$ was one of them. Home Schooling ABCD provides education starting at the preschool level where the majority of children with special needs are detected and begin to get stimulation and therapy [6]. This study aimed to identify forms of detection and stimulation of growth and development in children with delays in the city of Tegal.

\section{MATERIALS AND METHODS}

This study was a qualitative study with a phenomenological approach where the researchers were trying to dig up information related to the experience of informants in the implementation of detection and stimulation development in children with developmental delays or children with special needs. The study conducted from July-September 2019 at Home Schooling ABCD. The location selected because Home Schooling $A B C D$ is one of the formal education that handle children with special needs both with developmental delays or children with advanced development (7).

The informants in this study were taken using the snowball technique in which the retrieval of informants continued to increase until the data was saturated and obtained a total of 
5 informants consisting of one key informant, three main informants, and one triangulation informant. The key informant in this study was the Principal of Home Schooling ABCD, who was given the code "IK". Key informants provided direction to researchers about who could be key informants. The main informants in this study were educators and class therapists for children with special needs. The main informant was given the code "IU". This study also had a triangulation of informants, they were parents of students at Home Schooling ABCD who were given the code "IT" (8).

The data collection was carried out through focus group discussions (FGD), in-depth interviews, and document studies using interview guidelines and other supporting instruments such as cameras, voice recorders, and field notes. The data analyzed through the stages of reduction, presentation, and conclusion data. The validity of data tested uses triangulation methods; namely, researchers use more than one method to ensure the correctness of the data. The methods used include interviews with triangulation informants and documentation studies of instruments for detection and stimulation of children's development $(9,10)$.

\section{RESULTS AND DISCUSSION}

This study was conducted to explore information about the implementation of detection and stimulation of growth and development of children under five years old with developmental delays. The results of this study show that the implementation of growth and development detection has been carried out by Home Schooling $A B C D$ on an ongoing basis that is starting from the student's selection process and during the learning process. Screening is still carried out by Home Schooling during selection, even though the prospective students have previously been screened by experts such as pediatricians or by psychologists.
"Most of the children who study in our school are indeed children who experience developmental delays. Even though it is certain that the child is experiencing delays, we still have to do a developmental test to make sure where class they could enter and what kind of stimulation should be given." (IK. LS, August 6, 2019)

"Actually, we identified the type of delays by extracting information from parents from the beginning of the children get screening," (IU.AI, August 20, 2019)

"When parents brought their children to join the selection test, they usually knew already about what kind of delay their children had. Also, the parents told the selection team in the interview session" (IU.RH, Agust 20, 2019).

"In the beginning, We were interview first; what was the child achieve?" (IT. IM, August 24, 2019).

Detections made during the entrance selection are carried out using instruments that have been developed by the psychologist team. The instruments arrange according to the needs and conditions of the children who enter Home Schooling whom most of them detected with developmental delays. The results of the documentation study conducted on September 14, 2019 revealed that the instruments used had a level of content similarity with Denver II and KPSP. The instrument contains the development of cognitive or academic, social, and emotional abilities $(11,12)$. The instrument is used to see the form of delay but is not used to determine the diagnosis. Both instruments are instruments used by health workers such as pediatricians and midwives and cadres $(13,14)$.

Detection is carried out by the interviewer referring to the instrument - the questions are about academic ability, independence, compliance, emotions, and behaviour. In 
academic indicators, questions are about children's cognitive abilities such as the ability to arrange sentences, sing, spell, count, and distinguish colors. While emotions and behaviour, questions are about how to control and express emotions when at home.

Detection is also done by looking at the child's ability directly. Home Schooling ABCD applies a trial class where the child will have tested according to the child's developmental achievements based on the results of the previous interview. Prospective students will practice some form of activity to identify children's academic abilities, focus, and emotional control. In the trial class, children are not allowed to be accompanied by parents.

"Children attend the trial class first. We asked children to do development tests such as building blocks or mix and match images. From those activities, we can assess what developments need to be stimulated and what level of focus the children had" (IU. RH, August 20, 2019)

"in trial class we observed children ability, like the way he plays, he sits quietly, when learning must be calm, or have an eye contact. the trial class is program to see whether children abilities meet the checklist, any delays, whether this age has exceeded this development" (IU.AI, August 20, 2019)

"In trial class, the children instructed to show the color, enter the city box according to the number of balls in the box. When the selection of children can not be the same as parents" (IT. IM, September 24, 2019)

Based on the results of interviews and trial classes, Home Schooling ABCD determine the most appropriate class for children so that the stimulation provided by needs. Stimulation is planned and implemented by educators and therapists throughout the learning process. The majority of students are aged 6-7 years old, but the development achieved is only 3-5 years of age. Therefore the stimulation provided is adjusted to the child's achievements.

"We give per individual according to their needs, and we focus on one development before the other. We are more inclined to obedience or focus first. If obedience and focus reached, it will be easy to stimulate his brain" (IU. RH, August 20, 2019).

\begin{abstract}
"When stimulating and teaching children must be given step by step. One ability first, if the child has not mastered the child, could not move to the next stimulation. However, if the child has mastered the stimulation provided will increase. If it is given in unison, the child will not focus. As a result, the intended development was not achieved" (IU. FT, August 20, 2019).
\end{abstract}

"If the child did not train the focus, it is useless. Like broken glass, if it leaks no matter how much water-filled, it will not be full. So does the child. If the child could not focus, as much as any stimulation is given, it will not be mastered" (IU. AI, August 20, 2019).

"My daughter was hard to focus on. So at home, I also have to teach her to focus while studying. If she was unfocused, the learning must stop, or it could not be effective. I also need to be firm so she could learn to focus longer." (IT. IM, September 24, 2019).

What was done by the informants was in line with the results of the research by Hati and Lestari (15), which showed that stimulation would be useful if it paid attention to the needs of children according to their developmental stages. If children have more than one delay, the stimulation will focus on just one aspect. This method is done with the aim that the children are 
more focused on the following stimulation and can achieve the expected development.

"For example, seven years old children, but their ability are five years old, so we do not give lessons like an average of seven years children, but according to their achievement. The child has not only a motor impairment but also the focus." (IU. RH, August 20, 2019).

"My daughter has been able to distinguish colors, step by step she began to know colors like black, white, yellow, red, blue, and green. Even though, sometimes she is still confused to mention the right color. Later, if she had mastered the word, the stimulation will move forward to the next development, for example, recognizing numbers and letters. That cannot be direct either. Right now, my daughter learning to recognize numbers and letters. Just one number or letter. She takes a long time to master it." (IT. IM, September 24, 2019)

Efforts to increase focus are the main priorities made by Home Schooling. When children can focus, children will quickly master what was given. Previous study (16) stated that stimulating children with developmental delay by focusing on cognitive ability such as attention and concentration was an effective strategy to improve their ability.

"The key to the success of stimulation is parents. If the child only get stimulated at school but not at home, it is useless" (IU. RH, August 20, 2019)

The informant in the interview confirmed that the best stimulators are parents. Even though parents have involved experts or individual schools without participating in stimulating their children, the stimulation given to their children would be useless. Stimulation will be interrupted at home so the children cannot focus on doing the stimulation provided. The family is the main factor that can affect children's development. The family has a role in shaping a sense of care and responsibility, providing emotional support, and also social support, both verbal and nonverbal. The less family involvement, the higher the possibility for children to fail to achieve their development (17). Rajesh and Venkatesh (18) in their study also stated that by stimulating children's daily routines and make an intense interaction could change child ability. DeVeney et al. (19) stated that compared to clinicians or therapies, parents had more potential and more effective in improving children's development.

Students spend more time at home than at school. Unlike other schools with the fastest learning time was 6-8 hours, Home schooling $A B C D$ only provide 2 hours of learning because - generally — children have the optimal time to concentrate for approximately 2 hours. By optimizing the time, it was expected to get optimal results. Therefore, the development target would not be achieved if parents cut off the stimulation process. Each student provided with a contact book by the school - the book used as communication among therapists, educators, and parents. The books were beneficial in providing consistency and type of stimulation in children.

"Usually, we have a contact book that we use for giving a report every week. What the children learned in a week, we report it to their parents. From this book, we know how the children at home. Moreover, from this book we can find out how parents who in obedience by seeing children behaviour such as rage or hurting people" (IU.RH, August 20, 2019).

"Every week, we write down the form of stimulation or what has been taught and what needs to be done at home. Parents are asked to report feedback 
on what was done at home by the children." (IU.Al, August 20, 2019)

"Every parent was given a report book. We can know what lessons or stimulation given at school from that book. Besides that, the teacher also wrote notes for parents in the notes column about what kind of lessons or stimulation we should give to our children at home. Through the book, we also report the progress of the stimulation at home or what developments our children achieve." (IT. IM, September 24, 2019).

The majority of students at Home Schooling $A B C D$ experience developmental delay. In this condition, children have a particular food and beverage prohibition that needs to be consulted with experts because certain types of food or drink can cause children to lose focus so that the children's development is not optimal (20). In case of involving experts outside of learning hours without direct involvement of educators or school therapy was because educators were more focused on academic abilities. Then for specific abilities, there was a need for collaboration with experts.

\section{CONCLUSION AND RECOMMENDATION}

Detection of growth and development is carried out continuously by Home Schooling $A B C D$ as an educational institution that uses instruments that were developed without being done by interviewing parents and testing abilities in class trials - related to age assessments based on children's development. Early detection is used as material consideration in planning stimulation for children. Development stimulation is carried out during the learning process and followed by parents at home. The stimulation provided is focused on the earliest types of delays. If there are more than one delay, then the stimulation is continued on the next development when the children has mastered the previous development. This method helps children to be more focused on achieving the abilities they need to pursue.

\section{REFERENCES}

1. Liwang F, Soewito F. Optimalisasi Perkembangan Anak: Kunci Masa Depan Bangsa yang Sukses. J Indones Med Assoc. 2017;67(11).

2. Moonik P, Lestari H, Wilar R. Faktorfaktor yang Mempengaruhi Keterlambatan Perkembangan Anak Taman Kanak-kanak. J e-Clinic. 2015;3(1):124-36.

3. Proborini A, Maulidha, Larasati D. FaktorFaktor yang Mempengaruhi Keterlambatan Perkembangan Anak Usia 1-3 Tahun di Desa Cangkringsari Kecamatan Sukodono Kabupeten Sidoarjo. J Issues Midwifery. 2017;1(1):51-70.

4. Hendrawati S, Mardhiyah A, Mediani HS, Nurhidayah I, Mardiah W, Adistie F, et al. Pemberdayaan Kader Posyandu dalam Stimulasi Deteksi dan Intervensi Dini Tumbuh Kembang (SDIDTK) pada Anak Usia 0-6 Tahun di Desa Cileles Kecamatan Jatinangor Kabupaten Sumedang. Media Karya Kesehat. 2018;1(1):39-58.

5. Saputra WNE, Setianingrum I. Perkembangan Motorik Halus Anak Usia 3-4 Tahun Di Kelompok Bermain Cendekia Kids School Madiun Dan Implikasinya Pada Layanan Konseling. J CARE. 2016;3(2):1-11.

6. Sudarsana IK. Membentuk Karakter Anak Sebagai Generasi Penerus Bangsa Melalui Pendidikan Anak Usia Dini. Purwadita J Agama dan Budaya. 2017;1(1):41-8.

7. Murti B. Desain dan ukuran sampel untuk penelitian kuantitatif dan kualitatif dibidang kesehatan. Yogyakarta: Gadjah Mada University Press; 2013.

8. Prastiwi RS, Budihastuti UR, Wijaya M. Phenomenology Study:Factors Associated with theChoice of Unskilled Traditional Birth 
Attendants in Brebes, Central Java. J Matern Child Heal. 2016;01(04):242-9.

9. Milles MB, Huberman AM. Analisis Data Kualitatif; Buku Sumber tentang Metodemetode Baru. Jakarta: UI Press; 2014.

10. Sulaeman ES. Penelitian kualitatif dan Campuran dalam Kesehatan Masyarakat. Surakarta: UNS PRESS; 2015.

11. Izah N, Prastiwi R, Andari I. Stimulasi dan Deteksi Tumbuh Kembang Balita Usia 9-12 bulan Menggunakan Aplikasi Tumbuh Kembang Balita di Wilayah Kelurahan Margadana. J Pengabdi Masy Progresif Humanis Brainstorming. 2019;2(2):21-8.

12. Weitzman C, Wegner L, Blum NJ, Macias MM, Bauer NS, Bridgemohan C, et al. Promoting optimal development: Screening for behavioral and emotional problems. Pediatrics. 2015;135(2):384-95.

13. Susanti D, Sustini F. Implementation on Stimulation, Detection and Early Intervention of Child Growth and Development (SDIDTK) Program in Puskesmas Mojo, Surabaya still Emphasize on Growth Screening. Folia Medica Indones. 2017;52(1):51.

14. Utami S, Hargono R, Susilaningrum R, Kemenkes Surabaya P, Pucang Jajar Tengah no J, Keperawatan Universitas Airlangga F, et al. Kinerja Bidan dalam Deteksi Dini
Penyimpangan Tumbuh Kembang Anak. J Ners. 2016;11(2):201-9.

15. Hati FS, Lestari P. Pengaruh Pemberian Stimulasi pada Perkembangan Anak Usia 12-36 Bulan di Kecamatan Sedayu, Bantul. J Ners Midwifery Indones. 2016;4(1):44-8.

16. Thayathakath N. A Case Study: Cognitive Training for Children with Developmental Delay. J Psychosoc Res. 2018;13(1).

17. Fitriani IS, Oktobriariani RR. Stimulasi, Deteksi dan Intervensi Dini Orang Tua terhadap Pencegahan Penyimpangan Pertumbuhan dan Perkembangan Anak Balita. Indones J Heal Sci. 2017;1(1):1-9.

18. Rajesh V, Venkatesh L. Preliminary evaluation of a low-intensity parent training program on speech-language stimulation for children with language delay. Int J Pediatr Otorhinolaryngol. 2019;122:99-104.

19. DeVeney SL, Hagaman JL, Bjornsen $A L$. Parent-Implemented Versus Clinician-Directed Interventions for LateTalking Toddlers: A Systematic Review of the Literature. Commun Disord $Q$. 2017;39(1):293-302.

20. Utomo IWB, Maslihah M. Sistem Informasi Pola Diet Bebas Gluten dan Kasein untuk Anak Hiperaktif. Melek IT Inf Technol J. 2017;3(1). 